\title{
The influence of pore media distribution on the elastic parameters of rocks in Miocene sediments (Carpathian Foredeep, Poland, B deposit)
}

\author{
Maria Bała \\ AGH University of Science and Technology, Faculty of Geology, Geophysics and Environment Protection, \\ Department of Geophysics; al. Mickiewicza 30,30-059 Krakow, Poland; e-mail: bala@geol.agh.edu.pl \\ (C) 2015 Authors. This is an open access publication, which can be used, distributed and reproduced in any medium according \\ to the Creative Commons CC-BY 4.0 License requiring that the original work has been properly cited.
}

Received: February 2015; accepted: May 2015

Abstract: This paper presents the results of modelling compressional and shear wave velocities and elastic moduli, as well as Poisson's coefficient changes in sandstone-shale rocks, based on the distribution of media reservoir (water, gas) in the pore space. Modelling was performed using the Estymacja-TP computer program and theoretical Kuster-Toksöz and Biot-Gassmann relationships. Phase distribution of saturating pores (ellipsoidal shapes) in several ways was assumed. Calculations were made of elastic parameters in the deposits of the autochthonous Miocene Sarmatian in the borehole B-4. Using a method similar to the so-called "fluid substitution" velocity of compressional and shear waves, elastic moduli, Poisson's ratio and bulk density, under various conditions of water and gas saturation, were calculated. The assumed change in water saturation ranged from $S_{W}=0 \%$ to $100 \%$.

Keywords: P-wave velocity and S-wave velocity, theoretical Kuster-Toksöz model, Biot-Gassmann model, water and gas saturation, porosity

\section{INTRODUCTION}

The purpose of this study was to clarify, whether and how the media distribution in the pore space of reservoir rocks impacts the physical parameters' measurements in the well logging.

It was noted during the tests on the samples, that there were significant differences in wave velocity behavior with increasing and decreasing water sample saturation. With the increase in water saturation $\left(S_{W}\right)$ of up to about $80 \%$ (and thus decreasing air saturation), the velocity of the $\mathrm{P}$ wave $\left(V_{P}\right)$ showed little change, whereas in the range from $80 \%$ to $90 \%$, it increased dramatically.

However, when the water was removed from the same samples, the $V_{P}$ behavior was completely different. A "hysteresis" velocity in the range of $30-90 \%\left(S_{W}\right)$ (Endres \& Knight 1989) was observed. It was therefore concluded, that the cause of such changes in the elastic parameters, at the various techniques of saturation with water, and air samples, may be changes in the geometrical distribution of liquid and gas phase in the pores of the rock.

Calculations made using theoretical models of porous media confirmed the laboratory observations (Bała 1994).

The analysis of the effect of the distribution of water, oil and gas in the pores on the formation of elastic parameters can be carried out on the basis of theoretical models, such as the model developed by Kuster and Toksöz (Kuster \& Toksöz 1974, Toksöz et al. 1976), and Biot and Gassmann (Gassmann 1951, Biot 1956a, 1956b). 
The Estymacja-TP computer program was developed within the research the problem (Bała et al. 2003) and continued to be used in the following years (Bała et al. 2009-2012). It was described in detail in the publication (Bała \& Cichy 2006). The gained experience made it possible to use both of these models.

This article presents an analysis of the effect of the distribution of the media reservoir in the pores, on the elastic parameters of the Miocene sandstone rocks, using the example of the B structure.

Measurement of well logging and interpretation of quantitative results and laboratory data were made available by PGNiG SA, within the research project No NN525 363537, conducted in the years 2009-2012, under the direction of prof. M. Bała.

\section{GEOLOGICAL SETTING}

The structure B is located on the northern foreland Maćkowice gas deposits that lie in the eastern part of the Carpathian Foredeep, northwest of Przemyśl (Fig. 1).

Borehole B-4 was located in a place, where on the map of seismic attributes, an object of increased amplitude is distinguished, which may be due to gas saturation (The geological project in the area of B, PGNiG, Jasło, 2006).
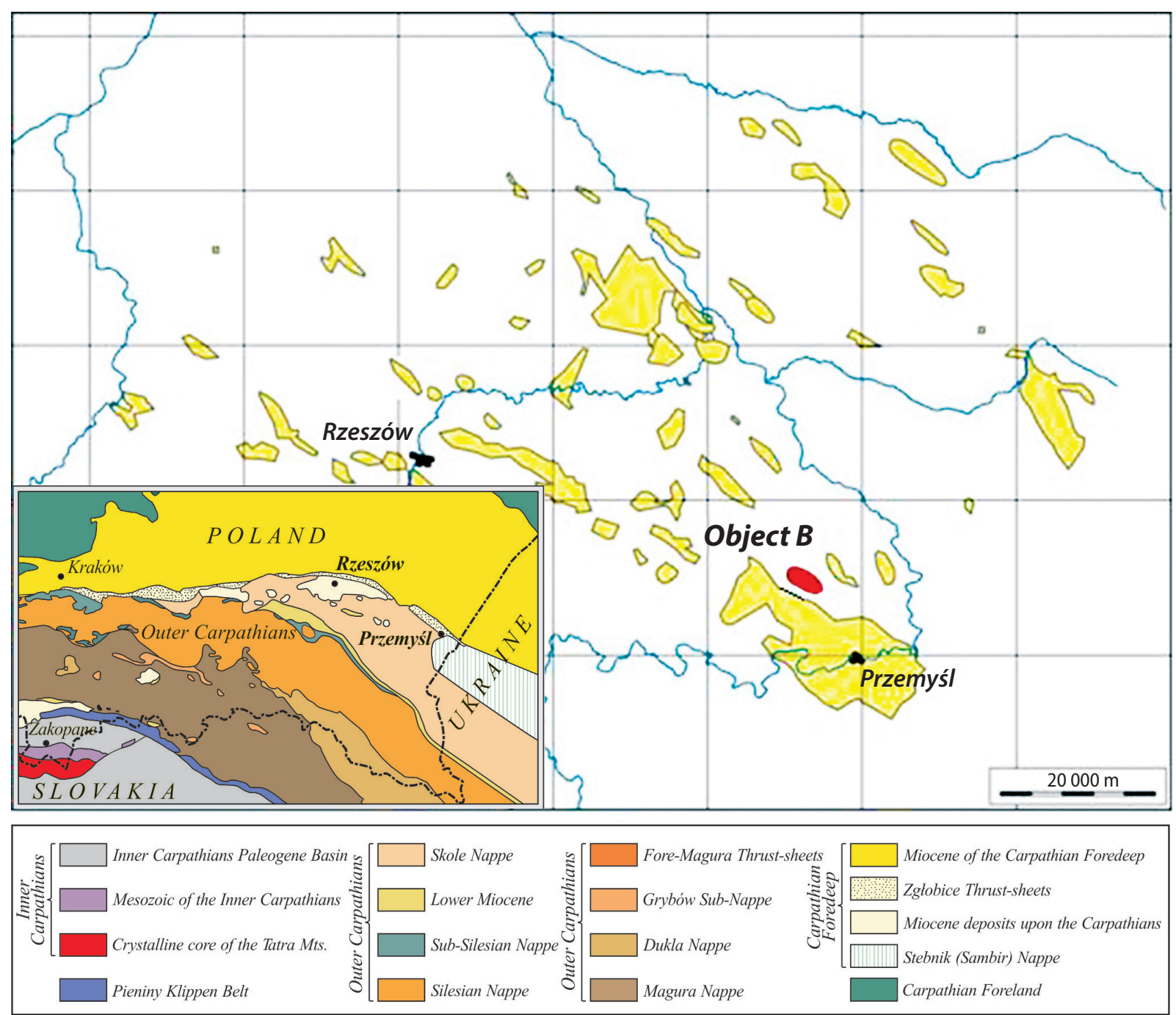

- boundary of Poland

Fig. 1. Geological sketch of the Carpathians and Polish Carpathian Foredeep; the location of object B (acc. to Myśliwiec 2004 modified, Oszczypko et al. 2008) 


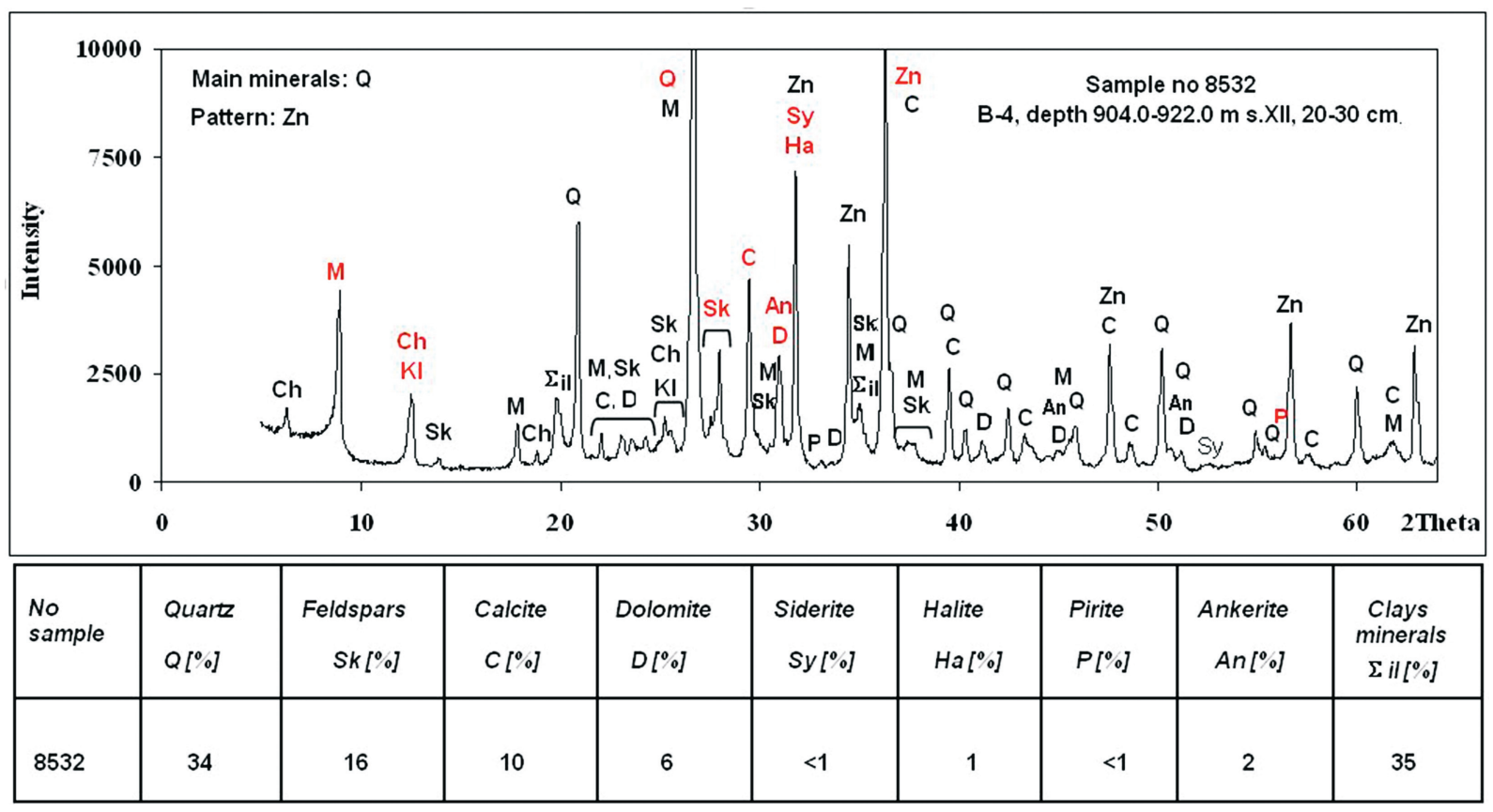

Fig. 2. X-ray diffraction and interpretation of the results of mineral composition of the sample taken from borehole B-4 (904.0-922.0 m, box. XII) (Zalewska, in: Bała et al. 2009-2012)

Based on geophysical measurements made in 488 holes, which lie in the region of Przemyśl-Jaksmanice, and taking into account the results of laboratory data from the reservoir series, 13 main gas-bearing horizons in an autochthonous Miocene were selected.

They are characterized by very high lithological variability in a vertical profile, as well as in the horizontal direction. These are clays, shales, mudstones and sandstones sometimes with significant thickness. The largest part series of sandstone occurs in the middle of the Sarmatian deposit. The average porosity of the sandstone reservoirs, determined from drill cores, varies from 9\% to $19 \%$ and permeability changes from a few to 600 $\mathrm{mD}$. All gas-bearing horizons have sufficient insulation between them, and the layers of shale are often of significant thicknesses (Karnkowski 1999).

Sarmatian sandstones consist of quartz and also contain a calcium carbonate admixture of different origins; namely: detrital fragments of limestone, dolomite and marl, that create sediment of autogenous cements.

These components are fragments of sedimentary, metamorphic and pyroclastic rocks. They also include mica, plagioclases, potassium feldspar and glauconite, as well as a small amount of heavy minerals, hydroxides of Fe and trace amounts of halite.
The binder is mainly calcite, but also cements of dolomite and detrital clays and mudstone fill occur.

Figure 2 shows an example of $\mathrm{X}$-ray diffraction, and the results of its interpretation (Zalewska, in: Bała et al. 2009-2012).

\section{MODELLING THE EFFECT OF GAS AND WATER ON THE ELASTIC PARAMETERS OF THE ROCKS}

We analyzed the effects of variable water saturation and gas contained in the pore space on the elastic parameters: velocity of longitudinal wave $\left(V_{P}\right)$ and shear wave $\left(V_{S}\right)$, the bulk modulus $(K)$, and shear modulus $(M I)$, Poisson's ratio $(N I)$ and the bulk density of rocks.

\section{Distribution of media in the reservoir pore space}

Kuster \& Toksöz (1974) assumed that the porous space may be expressed by a statistical distribution of the pore shape $a$ i.e. aspect ratio (ratio between the small and large axes in the ellipsoidal pores $\alpha=a / c)$.

The total porosity of this medium will be expressed by the sum of "concentration" pores 
("density" of the pores) for selected values of coefficient of $\alpha_{m, n}$ :

$$
\Phi=\sum_{m=1}^{M} \sum_{n=1}^{N} C\left(\alpha_{m, n}\right)
$$

where:

$C\left(\alpha_{m, n}\right)$ - concentration of pores having the aspect ratios $\alpha_{m, n}$,

$m=1, \ldots, M-$ the number of coefficients of pore shapes,

$n=1, \ldots, N$ - the number of components of the media saturating individual pores (water, oil, gas).

Distribution of media, which saturate the pore space can be assumed in three ways (Kuster \& Toksoz 1976, Bała 1989, Endres \& Knight 1989):

- Option 1: Media filling the pores mixed or dissolved, creating a homogeneous solution (the so-called "Patchy model"). Moduli of elasticity for such a medium introduced into the equations Kuster-Toksöz, can be calculated from the linear relationship.

- Option 2: Pore media do not mix. This case may correspond to the example gas bubbles in the brine. Modulus $K_{f}$ can be calculated using Wood's formula (eg. Bała 1989, 1994):

$$
\frac{1}{K_{f}}=\frac{V_{W}}{K_{W}}+\frac{V_{G}}{K_{g}}
$$

where:

$K_{f}$ - bulk modulus of the pore fluid,

$V_{W}, V_{G}$ - the volume of each phase,

$K_{W}, K_{g}$ - bulk moduli of water and gas phases.

- Option 3: Pore-saturating fluid is made up of a number of components, each filling separate pores. For example, the gas initially occupies the narrow pores with lower aspect ratios $\alpha_{m}$, but with the increase in $V_{G}$, the larger pores are saturated $\alpha_{m}$.

Yet another option is shown in the work Brie et al. (1995):

$$
K_{f}=\left(K_{W}-K_{g}\right) \cdot V_{W}^{e}+K_{g}
$$

where $e$ is constant.

Figure 3 shows the calculated longitudinal wave velocity $V_{P}$ depending on the saturation of gas and water pore space of the rock.

Figure 3 shows the calculated velocity $V_{P}$ depending on the saturation of gas and water pore space of the rock.

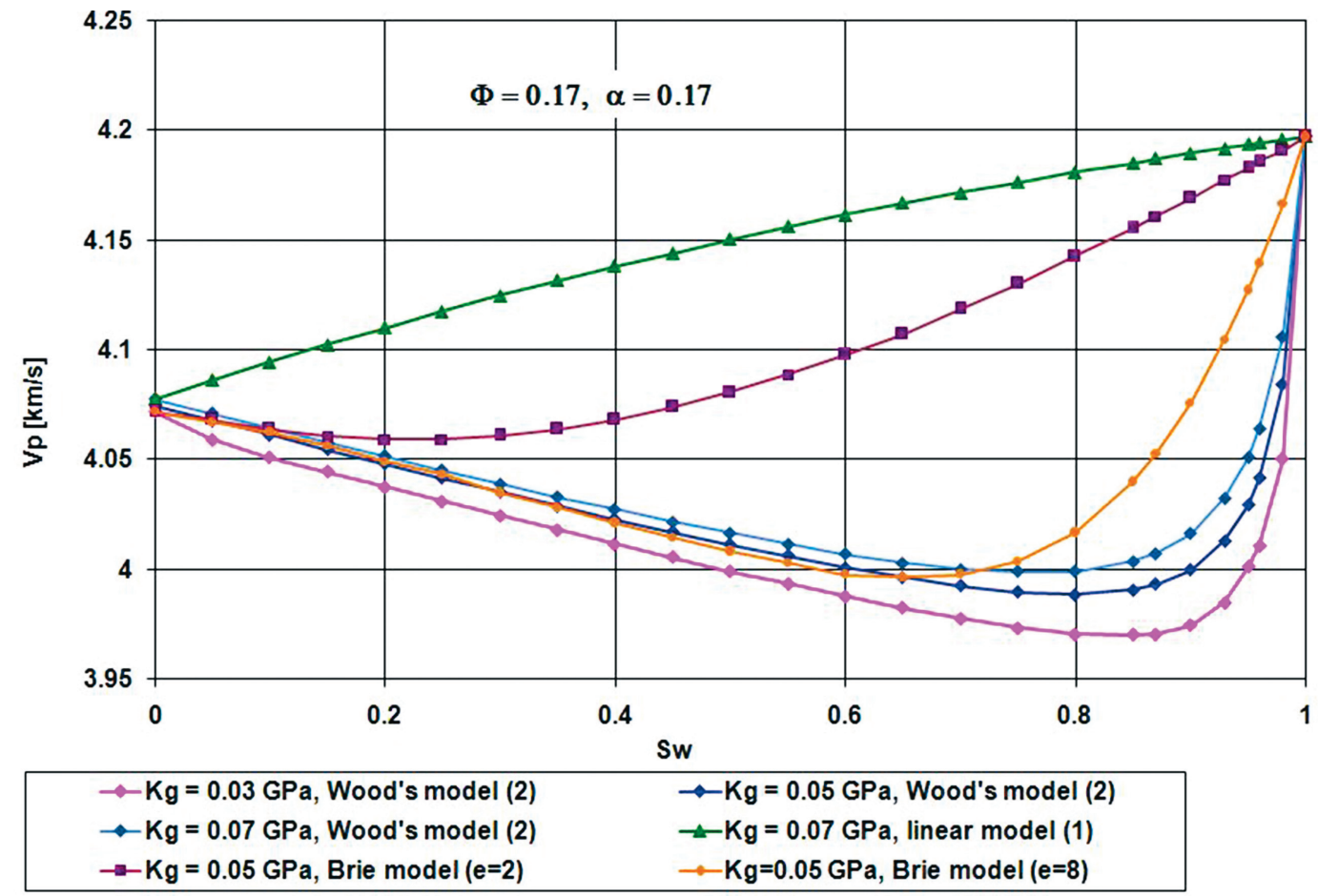

Fig. 3. The relationship between $V_{P}$ vs. water saturation $S_{W}$ with various distributions and water and gas phases; $\alpha=0.17$ and $\Phi=0.17$ are assumed. Calculations were performed using the Kuster-Toksöz model; options 1 and 2 were assumed and depended on the use of the Brie model (Brie et al. 1995) 
Distribution of the water phase and the gas was assumed according to variant 1 and 2 . The calculations were made for the Miocene sandstone of the average porosity $\Phi=0.17$ and an average pore distribution $\alpha_{m}=0.17$.

The following values were assumed for the bulk modulus of gas $K_{g}=0.03,0.05$ and $0.07 \mathrm{GPa}$, which correspond to changes in this parameter with the increase in pressure (also with depth - Bała et al. 2009-2012); for water $K_{W}=2.4 \mathrm{GPa}$.

On the graph, the dependence of $V_{P}=f\left(S_{W}\right)$ was plotted, calculated by using the Brie model (Brie et al. 1995), in which $e=2$ and 8 were constant. At high values of $e$ (e.g. $e=8$ or higher), the shape of curve $V_{P}=f\left(S_{W}\right)$ becomes somewhat similar to the curves calculated according to option 2 . The modelling results show that options 1,2 and Brie give very different values of $\mathrm{P}$-wave velocity $\left(V_{P}\right)$, as a function of water saturation $\left(S_{W}\right)$. These behave similarly to other elastic parameters, such as bulk's modulus $(K)$ or Young's modulus $(E)$. Option 2 shows that the presence of even a small amount of gas saturation of the pores brings about a strong decrease in P-wave velocity. Such small gas saturation can generate seismic anomalies, similarly as in the case of industrial content.

This problem also occurs in the search for natural gas in the Miocene sediments of the Carpathian Foredeep (Myśliwiec 2004) and was the subject of the research project No. NN525 363537 (Bała et al. 2009-2012, as well Marzec et al. 2014).

\section{Calculation of elastic parameters in the Miocene deposits using the Estymacja-TP software}

The study of variation of elastic parameters in borehole B-4 was performed as follows: in the first phase of the calculations the results of quantitative interpretation of well logging data were used volume fraction of mineral content (VSAND, VLIM), the volume fraction of clay (VSH) content, the coefficients of porosity (PHI), and water saturation in the flushed and uninvaded zones $\left(\mathrm{SXO}, S_{W}\right)$.

Velocities of the longitudinal and transverse waves (VPEQ, VSEQ) and elastic modulus EEQ, KEQ, MIEQ, the relations VPEQ/VSEQ and Poisson's ratio (NIEQ), and bulk density RHEQ, as a function of depth, using of the Estymacja-TP software, were calculated (symbol EQ was introduced to emphasize that the parameter was calculated using the theoretical relation).

The latest version of the Estymacja-TP program was applied (Bała et al. 2012, research project No $\mathrm{N}$ N525 363537). This program is an extended version of Estymacja (Bała \& Cichy 2006) supplemented with the option of automatic conversion of the density and modulus of elasticity for gas, oil and water from the change in pressure, temperature and chemical composition of the media reservoir (Batzle \& Wang 1992, Bała 2001).

The program uses the theoretical Biot-Gassmann models (BG), Kuster-Toksöz models (KT) and Wyllie relations (W) and Raymer-HuntGardner relations (RHG).

Before using the calculation program, one must specify the matrix parameters.

We selected them suggesting a mineral composition of sandstone, also taking into account quartz admixtures of other minerals (based on analyzes of cores). The composition of the shale in the Miocene deposits is often made up of minerals of the illite / smectite group, chlorite, as well as a large amount of mica (Ciechanowska et al 2004).

An important criterion for assessing the parameters of the skeleton is to minimize the error of calculation of the estimated transit interval time DTEQ longitudinal wave, compared to the measured time DT (PA).

Figure 4 shows the results of the interpretation provided by the Estymacja-TP program in the selected interval of $828.95 \mathrm{~m}$ to $853.85 \mathrm{~m}$.

On the first track of the interval transit time curves, P-wave $[\mu \mathrm{s} / \mathrm{m}]$ measured (black) and calculated theoretically (red) are marked. For the second track the calculated interval transit time S-wave $[\mu \mathrm{s} / \mathrm{m}]$ is marked. On the following: neutron porosity curve [in a friction], then bulk density $\left[\mathrm{g} / \mathrm{cm}^{3}\right]$ (black curve) and theoretically calculated bulk density (red curve) are marked. Next, interpreted from the logging data water saturation $\left(S_{W}\right)$ is marked in blue and gas (pink). The resistivity of flushed zone (RXO) [ohm], the estimation error [\%], followed by mineral composition and porosity interpreted from the data of well logs and finally the ratio VPEQ/VSEQ.

In the high gas saturation zone of 840-849 m, one can notice the increased transit interval time of the P-wave (the figures marked as DPEQ) and an increase in apparent resistivity and reduction in 
of bulk density (RHEQ), neutron porosity (NPHI) and the ratio of VPEQ/VSEQ.

The porosity of the neutron is reduced due to the reduction of the hydrogen index (HI) in the gas-bearing zone in relation to the water zones.

Curve VPEQ/VSEQ reflects the lithology and saturation of water and gas. Gas significantly reduces the ratio VPEQ/VSEQ for the discussed layer, varying between $1.53-1.58$ while in the water saturation zones it is more than 1.6. The local increase in the ratio of the VPEQ/VSEQ is due to the presence of carbonates occurring in the cement rock.

For comparison, Figure 5 shows the result of the interpretation of full acoustic waveforms recorded by acoustic logging, using the application Wave FWS system GeoWin (Jarzyna et al. 2002). The figure shows the calculated interval transit time (i.e., inverse of velocity) of $\mathrm{P}, \mathrm{S}$ and Stoneley waves, the ratio $V_{P} / V_{S}$ and Poisson's ratio $(N I)$ in the interval from $839.0 \mathrm{~m}$ to $849.0 \mathrm{~m}$ marked in yellow.

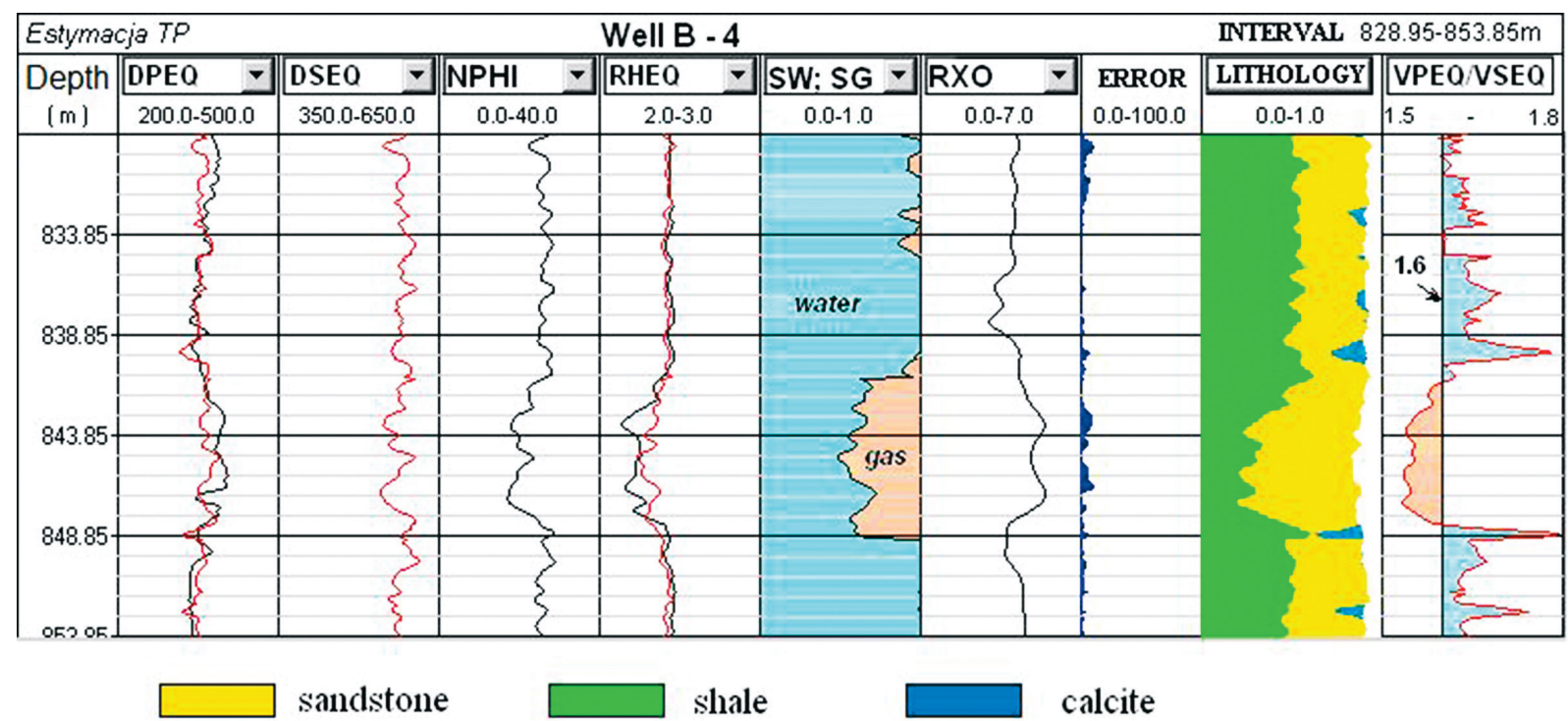

Fig. 4. Summary of the parameters calculated for a selected depth interval (828.95-853.85 m) from well B-4, associated with sandstone and mudstone strata of the autochthonic Miocene. Red curves calculated using Estymacja, black curves were recorded (Projekt prac geologicznych $w$ rejonie Batycze, PGNiG Jasło, 2006). The Estymacja-TP program and Biot-Gassmann model were used

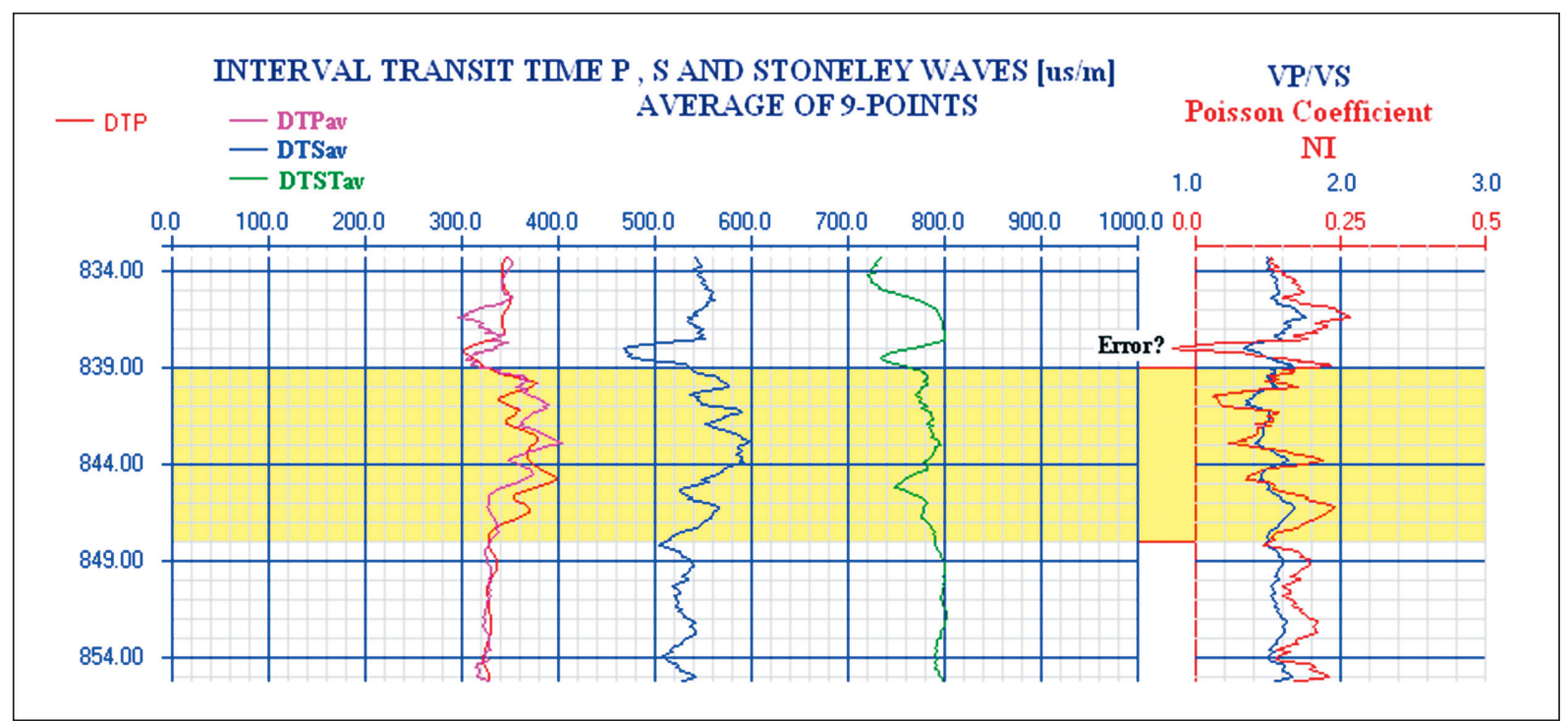

Fig. 5. The results of automatic interpretation for the layer of the interval from $830.0 \mathrm{~m}$ to $852.0 \mathrm{~m}$ (Fala FWS GeoWin ${ }^{\circledR}$ system) (Jarzyna et al. 2002) 
A noticeable increase in the interval transit time of the longitudinal wave and the shear wave is evident. The $\mathrm{P}$ wave reaches the interval transit time up to $400 \mu \mathrm{s} / \mathrm{m}$, and $\mathrm{S}$ wave to $598 \mu \mathrm{s} / \mathrm{m}$. Such a high transit interval time is the result of a layer of gas saturation.

Poisson's ratio depicted in the top layer, reaching a value lower than zero, should be regarded as a system error. This is due to the impossibility of accurately determining the first break of the S wave in the loosened rock (Bała \& Jarzyna 1992).
A comparison of curves calculated using theoretical models and interpretation of the acoustic waveforms show a large similarity in the results.

Tables 1-3, listed below, show the values of the minimum, maximum and average values of parameters calculated using the model of Biot-Gassmann, sequentially for the intervals containing water-bearing horizons (642.04-686.94 $\mathrm{m}$ ), the gas-bearing layer (840-849 $\mathrm{m}$ ) and the large clayey zones (1478.59-1523.39 m).

Table 1

The minimum, maximum and average parameters calculated using the Estymacja-TP program. The shale-sandstones zone is saturated with water

\begin{tabular}{|l|l|c|c|c|}
\hline \multicolumn{5}{|c|}{ Zone of sandstones with shale - interval from 642.0 m to 686.9 m } \\
\hline \multirow{2}{*}{ The calculated parameters } & Minimum & Maximum & Average \\
\hline \multirow{2}{*}{ The velocities [km/s] } & VPEQ & 2.66 & 2.98 & 2.81 \\
\cline { 2 - 5 } & VSEQ & 1.60 & 1.85 & 1.70 \\
\hline \multirow{2}{*}{ Ratio of VPEQ/VSEQ } & & 1.61 & 1.73 & 1.65 \\
\hline Poisson's coefficient & NIEQ & 0.18 & 0.25 & 0.21 \\
\hline \multirow{2}{*}{ Dynamic of elastic moduli [GPa] } & EEQ & 15.03 & 20.35 & 17.04 \\
\cline { 2 - 5 } & KEQ & 8.41 & 11.11 & 9.77 \\
\cline { 2 - 5 } & MIEQ & 6.13 & 8.60 & 7.05 \\
\hline \multirow{2}{*}{ Bulk density $\left[\mathrm{kg} / \mathrm{m}^{3}\right]$} & RHEQ & 2370 & 2500 & 2430 \\
\hline
\end{tabular}

Table 2

The minimum, maximum and average parameters calculated using the Estymacja-TP program. The sandstone layer saturated with gas

\begin{tabular}{|l|l|c|c|c|}
\hline \multicolumn{5}{|c|}{ Series of gas saturation sandstones - interval from 840 m to 849 m } \\
\hline \multirow{2}{*}{ The calculated parameters } & Minimum & Maximum & Average \\
\hline \multirow{2}{*}{ The velocities [km/s] } & VPEQ & 2.56 & 2.86 & 2.62 \\
\cline { 2 - 5 } & VSEQ & 1.53 & 1.84 & 1.55 \\
\hline Ratio of VPEQ/VSEQ & & 1.54 & 1.59 & 1.56 \\
\hline Poisson's coefficient & NIEQ & 0.13 & 0.18 & 0.15 \\
\hline \multirow{2}{*}{ Dynamic of elastic moduli [GPa] } & EEQ & 13.91 & 18.51 & 16.40 \\
\cline { 2 - 5 } & KEQ & 6.56 & 8.64 & 7.77 \\
\cline { 2 - 5 } & MIEQ & 6.07 & 8.10 & 7.15 \\
\hline \multirow{2}{*}{ Bulk density $\left[\mathrm{kg} / \mathrm{m}^{3}\right]$} & RHEQ & 2240 & 2400 & 2330 \\
\hline
\end{tabular}


Table 3

Minimum, maximum and average parameters calculated using the Estymacja-TP program. The series of shale-sandstone rocks

\begin{tabular}{|l|l|c|c|c|}
\hline \multicolumn{5}{|c|}{ Series of shale-sandstone rocks - interval from 1478.6 m to 1523.4 m } \\
\hline \multirow{2}{*}{ The calculated parameters } & Minimum & Maximum & Average \\
\hline \multirow{2}{*}{ The velocities [km/s] } & VPEQ & 2.77 & 3.28 & 3.08 \\
\cline { 2 - 5 } & VSEQ & 1.70 & 2.05 & 1.90 \\
\hline Ratio of VPEQ/VSEQ & NIEQ & 1.68 & 1.78 & 1.72 \\
\hline Poisson's coefficient & EEQ & 0.18 & 0.27 & 0.24 \\
\hline \multirow{2}{*}{ Dynamic of elastic moduli [GPa] } & KEQ & 16.37 & 24.84 & 21.27 \\
\cline { 2 - 5 } & MIEQ & 8.76 & 15.33 & 11.61 \\
\hline $\begin{array}{l}\text { Bulk density } \\
{\left[\mathrm{kg} / \mathrm{m}^{3}\right]}\end{array}$ & RHEQ & 6.83 & 10.54 & 8.91 \\
\hline
\end{tabular}

The results show, that higher values of average velocity $\mathrm{P}$ and $\mathrm{S}$ waves can be observed in water-bearing sandstone with respect to saturated gas. The ratio of wave velocity VPEQ/VSEQ is the lowest in a series of gas-bearing rocks, higher in the sandstone of water saturations and even higher in the series of shale-sandstone rocks. The Poisson's ratio behaves in a similar manner, indicating a very low value in the levels of saturated gas.

\section{Study of the effect of variable pore saturation of gas and water on the elastic parameters of the Miocene deposits in the borehole B-4}

For the modelling of the effect of variable water saturation and gas on the elastic parameters of the rocks, the Estymacja-TP program and theoretical Biot-Gassmann model were also used.

The applied methods were similar to the known literature methods "fluid substitution" discussed, among others, in Dvorkin et al. (2007) and Mavko et al. (1995). The author used this modified method many times, and the results are presented in publications (for example Bała 2007). The method is based on using substitution in the zones, showing the presence of hydrocarbons, the value of saturation from the $S_{W}=0.0\left(S_{G}=1\right.$ total gas saturation), to $S_{W}=1\left(S_{G}=0.0\right.$ absence of hydrocarbons).

The input parameters are the same as in the initial calculations with the real saturation. The calculation results are shown in Figures 6 and 7, for the selected depth interval.

Figure 6 shows the calculated velocities $P$ and $S$ waves and bulk modulus and shear modulus at the following values of saturation: $S_{W}=$ Real (real saturation: VPEQ, VSEQ, KEQ, MIEQ), $S_{W}=0$ (total gas saturation: VP00, VS00, KE00, MI00), $S_{W}=1.0$ (total water saturation: VP10, VS10, KE10, MI10), $S_{W}=0.95$ (water saturation $S_{W}=0.95$ : VP95, VS95, KE95, MI95) and $S_{W}=0.8$ (water saturation $\left.S_{W}=0.8: \mathrm{VP} 08, \mathrm{VS} 08, \mathrm{KE08}, \mathrm{MI08}\right)$. The orange marked area between $S_{W}=0.0$ and $S_{W}=1.0$.

The first track shows lithology and porosity (SHALE, SAND, LIME, PHI), and gas saturation $\left(S_{G}\right)$ (red curve). The following paths are in the order: velocity of P-wave, velocity of S-wave, bulk modulus and shear modulus.

As can be observe, the P-wave velocity is lower at saturation $S_{W}=0.8$ (brown curve) than at a total gas saturation $S_{W}=0.0$ (red curve). The S-wave velocity and shear modulus (MI) behave differently and show no change with saturation. Bulk modulus $(K)$ shows a large reduction at the total gas saturation $\left(S_{W}=0.0\right)$. In the water-bearing zones, all curves overlap. 


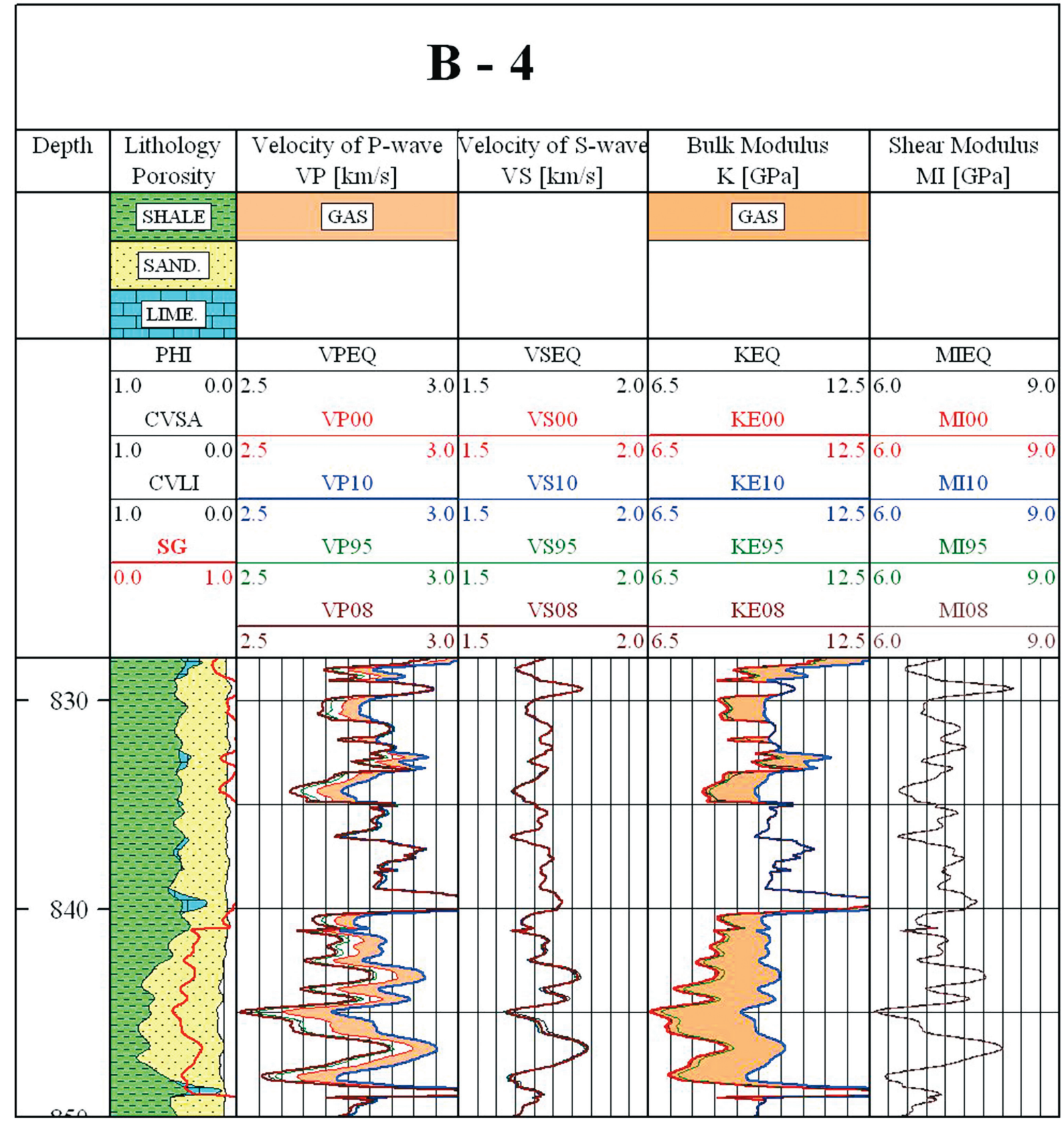

Fig. 6. Summary of the calculated velocity of longitudinal waves, shear waves, bulk modulus and shear modulus in the interval from $828.0 \mathrm{~m}$ to $855.0 \mathrm{~m}$ (symbols $E Q$ means real saturation of water)

Figure 7 shows the curves in the following order: ratio $V_{P} / V_{S}$, Poisson's coefficient, bulk density and acoustic impedance of P-wave for the same interval of a depth between $828.0-855.0 \mathrm{~m}$.

In the gas-saturated zones, the lowest values of the ratio $V_{P} / V_{S}$ were observed at low water saturations $\left(S_{W}=0.0\right)$. However the presence of a small amount of gas in the pore spaces significantly reduces the ratio of both waves, with similar behavior as in Poisson's ratio (NI). Bulk density values increase linearly with increasing water saturation, i.e., the lowest densities are associated with total gas saturation.

The character of the variability P-wave velocity and bulk density in relation to water saturation in selected strata having different porosity (PHI) and clay content by volume (VSH), as is shown by Figure 8A, B. 


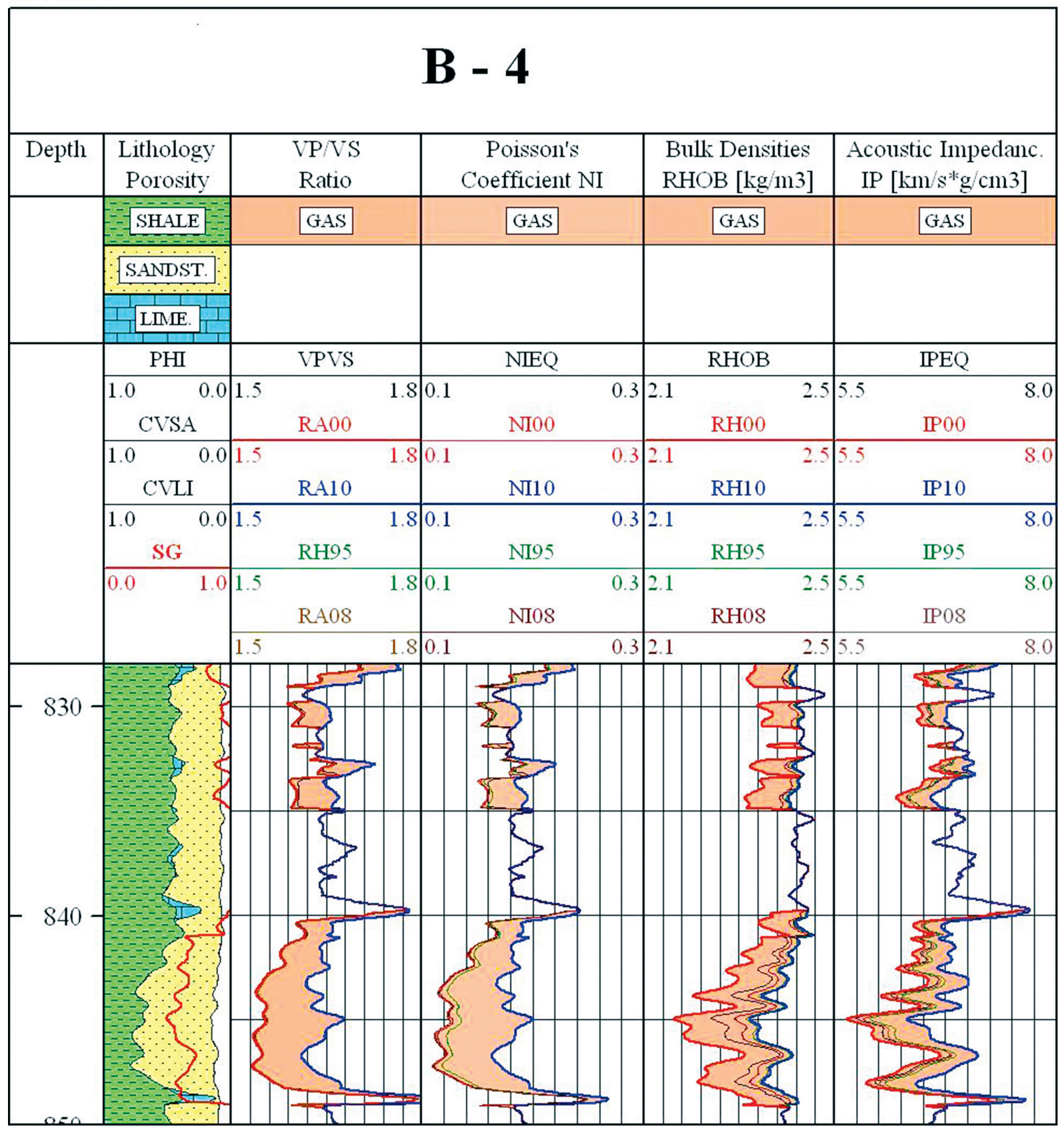

Fig. 7. Summary of calculated ratio of $V_{P} / V_{S}$, Poisson's coefficient, bulk density and acoustic impedance of $P$-wave in the interval of $828.0-855.0 \mathrm{~m}$

The parameters describing subsequent layers are summarised in Table 4 . Sand content by volume (VSAND) and real saturation of each layer (SWReal) are also included.

When pores are fully saturated with gas $\left(S_{W}=0.0\right)$, the VPEQ value is less than the value of that at total water saturation $\left(S_{W}=1.0\right)$. Reduction of gas saturation reduces the VPEQ.

Analysis of Figure 8A and Table 4 suggests that both porosity and mineral content have an important impact on the character of $\mathrm{P}$-wave velocity changes (VPEQ). Its lowest values are observed in layer 6, which is associated with the highest values of porosity. Minimum values are apparent in all layers, where water saturation has a value of $S_{W}=0.85$, which corresponds with a gas saturation of $15 \%$. Between $S_{W}=0.95$ and 1.0 , the value of $\mathrm{P}$-wave velocity increases rapidly.

A significant velocity decrease is also apparent where the gas content in rock pores is low. The 

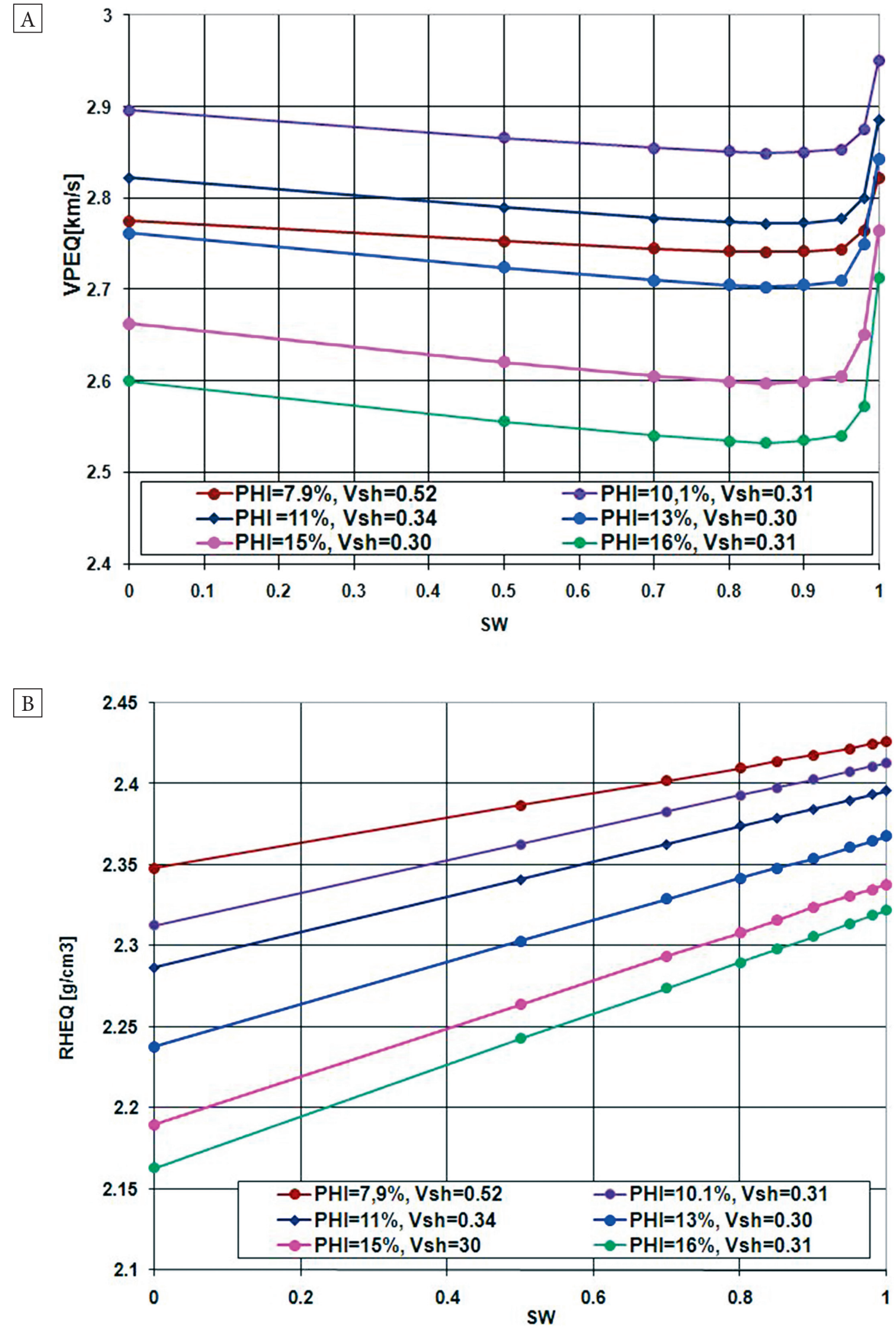

Fig. 8. Relationship between the P-wave velocity VPEQ (A) and bulk density RHEQ (B) as a function of water saturation SW. Selected layers there are between 841.0-846.0 m 
presence of only a small percent of gas results in a velocity reduction of nearly $40 \%$ in relation to values associated with total water saturation. Such a situation may lead to highly ambiguous interpretations during gas exploration studies. When the porosity is low, velocity changes associated with a variable saturation are significantly less (as shown by layer 1 ).

Bulk density shows a linear increase in value with increasing water saturation (Fig. 8B).

\section{Table 4}

Parameters for selected layers used in the calculation

\begin{tabular}{|c|c|c|c|c|c|}
\hline $\begin{array}{c}\text { Depth } \\
{[\mathbf{m}]}\end{array}$ & $\begin{array}{c}\text { Poros- } \\
\text { ity } \\
\text { PHI } \\
{[\%]}\end{array}$ & $\begin{array}{c}\text { Volume } \\
\text { of quartz } \\
\text { VSAND } \\
{[\%]}\end{array}$ & $\begin{array}{c}\text { Vol- } \\
\text { ume } \\
\text { of clay } \\
\text { VSH } \\
{[\%]}\end{array}$ & $\begin{array}{c}\text { Bulk } \\
\text { density } \\
\text { RHOB } \\
{\left[\mathbf{k g} / \mathbf{m}^{3}\right]}\end{array}$ & $\begin{array}{c}\text { Real } \\
\text { water sat- } \\
\text { uration } \\
\text { SW real } \\
\text { [fraction] }\end{array}$ \\
\hline 841.3 & 7.9 & 40.1 & 52.0 & 2410 & 0.698 \\
\hline 846.6 & 10.1 & 59.9 & 31.0 & 2380 & 0.722 \\
\hline 844.2 & 11.0 & 55.0 & 34.0 & 2360 & 0.604 \\
\hline 844.0 & 13.0 & 57.0 & 30.0 & 2320 & 0.563 \\
\hline 844.7 & 15.0 & 55.0 & 30.0 & 2270 & 0.515 \\
\hline 844.9 & 16.0 & 53.0 & 31.0 & 2240 & 0.489 \\
\hline
\end{tabular}

\section{DISCUSSION AND CONCLUSIONS}

Elastic parameters, which included P-and S-wave velocities, their ratios, as well as the bulk and shear moduli, Poisson's ratio and the bulk density of rocks were all calculated using the Estymacja-TP program, utilising the Biot-Gassmann and KusterToksöz models available. The influence of variable gas saturation on the above parameters was determined, based on forward modeling, using a method similar to the "fluid substitution" method.

The elastic parameters of the rock affect not only the saturation of the gas but also, the distribution of the gaseous phase and the water phase in the pore space.

The calculations using the Kuster-Toksöz formulas, allowed us to model the distribution of two phases (water and gas) saturating the ellipsoidal pore shapes. Option 2, when the pore media do not mix (this case may correspond to e.g. gas bubbles in brine) confirms the presence of very strong changes $V_{P}$, even already at low, on the order of several $1 \%$, gas saturation of the pore space. Such a low saturation of gas may generate seismic anomalies, as in the case of industrial content.

In analyzing the tables showing the minimum, maximum and average values of the calculated parameters and the results obtained using the "fluid substitution" method, one can draw the following conclusions:

- The presence of gas reduces the velocity P-waves, Young's modulus, bulk modulus, ratio $V_{P} / V_{S}$, Poisson's ratio and bulk density.

- The presence of the gas does not substantially influence the velocity of the S-wave and shear modulus.

- In the intervals saturated with water, the elasticity parameters depend on the lithological composition of the rock. The ratio $V_{P} / V_{S}$ for sandstone-clayey rocks is between 1.6 and 1.73, depending on the proportion of sandstone and clay fractions. The increase in the presence of clays increases the $V_{P} / V_{s}$.

- Admixtures of carbonates in a clayey sandstone series cause an increase in the value of elastic parameters.

- Changes in the relative proportions of saturated pore gas and water formation strongly influence the P-wave velocity and Young's modules, bulk modulus and $V_{P} / V_{S}$.

- Minimum VPEQ reaches at $S_{W}=0.85\left(S_{G}=0.15\right)$, while between $S_{W}=0.95$ and 1.0 , the value of $\mathrm{P}$-wave velocity increases rapidly.

- Bulk density (RHEQ) shows a linear increase in value with increasing water saturation.

The author would like to thank PGNiG S.A. Poland for access to well log data necessary for the realization of the research project No NN525 363537.

The research presented here was partly carried out within the framework of the research project No NN525 363537 supervised by M. Bała in 2009-2012, financed by the Ministry of Science and Higher Education, and partly from statutory research performed in the Department of Geophysics WGGiOS AGH in 2009.

\section{REFERENCES}

Bała M., 1989. Analiza obrazu falowego zarejestrowanego przy profilowaniu akustycznym w odwiercie pod kątem oceny parametrów sprężystych i zbiornikowych skał. Zeszyty Naukowe AGH, Geofizyka Stosowana, 3, 1247 [with English summary]. 
Bała M., 1994. Effect of water and gas saturation in layers on elastic parameters of rock sand reflection coefficients of waves. Acta Geophysica Polonica, 42, 2, 149-158.

Bała M., 2001. Analiza wpływu obecności gazu w porach skalnych na prędkość fal sprężystych na przykładzie wybranych horyzontów złoża „R”. Przegląd Geologiczny, 49, $1167-1175$.

Bała M., 2007. Application of well logging data to determine a model of elastic parameters for the Księżopol gas reservoir in the autochthonous Miocene formations. 13th European Meeting of Environmental and Engineering Geophysics, Near Surface, Istanbul, Turkey.

Bała M. \& Cichy A., 2006. Metody obliczania prędkości fal $P$ i S na podstawie modeli teoretycznych i danych geofizyki otworowej - program Estymacja. Uczelniane $\mathrm{Wy}-$ dawnictwa Naukowo-Dydaktyczne AGH, Kraków [with English summary].

Bała M. \& Jarzyna J., 1992. System of Automatic Interpretation of Full Waveform Recorded During Acoustic Logging. Acta Geophysica Polonica, 40, 1, 49-61.

Bała M., Jarzyna J., Cichy A. \& Such P., 2003. Modelowanie prędkości propagacji i tłumienia fal sprężystych podtużnych i poprzecznych $w$ skałach porowatych $w$ powiązaniu $z$ otworowymi badaniami geofizycznymi. Projekt badawczy KBN Nr 8T12B 04620 [with English summary].

Bała M., Cichy A., Drabina A., Kobylarski M., Krawiec J., Ossowski A., Pietsch K., Rzemieniarz A., Witek K., Woźnicka U., Zorski T. \& Danek T., 2008. Modelowanie wpływu zmiennego nasycenia gazem przestrzeni porowej skał na wyniki pomiarów akustycznych i innych profilowań $w$ otworach oraz sejsmicznych pól falowych: projekt badawczy nr 4 T12B 05629, 10.2005-04.04.2008. Arbor, Kraków [with English summary].

Bała M., Cichy A., Jarzyna J., Mortimer Z., Pietsch K., Puskarczyk E., Marzec P., Witek K. \& Niepsuj M., 2009_ 2012. Modelowania teoretyczne i empiryczne wplywu zmiennego ciśnienia i nasycenia gazem na parametry sprężyste, gestość i oporność skat dla oceny przepuszczalności $z$ danych geofizyki otworowej. Projekt badawczy nr NN525 363537, Akademia Górniczo-Hutnicza im. St. Staszica w Krakowie, Kraków [with English summary].

Batzle M. \&Wang Z., 1992. Seismic properties of pore fluids. Geophysics, 57, 11, 1396-1408.

Biot M.A., 1956a. Theory of Propagation of Elastic Waves in a Fluid-Saturated Porous Solid. I. Low-Frequency Range. The Journal of the Acoustical Society of America, 28, 2, 168-178.

Biot M.A. 1965b. Theory of Propagation of Elastic Waves in a Fluid-Saturated Porous Solid. II. Higher Frequency Range. The Journal of the Acoustical Society of America, 28, 2, 179-191.

Brie A., Pampuri F., Marsala A.F. \& Meazza O., 1995. Shear sonic interpretation in gas-bearing sands. SPE Annual Technical Conference and Exhibition, 22-25 October, Dallas, Texas, paper SPE-30595-MS, 701-710.

Cadoret T., Marion D. \& Zinszner B., 1992. 1 kHz elastic wave velocities in partially saturated limestones: evidence of fluid distribution effect. $62^{\text {nd }}$ SEG Annual Meeting, 25-29 October, New Orleans, Louisiana, Expanded Abstracts, paper SEG-1992-0658, 658-666.
Ciechanowska M. \& Zalewska J., 2004. Porównanie wskaźników struktury porowej określonych z modelu Archiego i Waxmana-Smitsa dla rdzeni wiertniczych $\mathrm{z}$ otworów Chałupki Dębnianiańskie-3 i Jasionka-4. Konferencja naukowo-techniczna Geopetrol 2004 nt. Efektywne technologie poszukiwania i eksploatacji złóż węglowodorów, Prace Instytutu Nafty i Gazu 130, INiG, Kraków, 819823 [with English summary].

Dvorkin J., Mavko G. \& Gurevich B., 2007. Fluid substitution in shaley sediment using effective porosity. Geophysics, 72, 3, 1-8.

Enders A.L. \& Knight R., 1989. The effect of pore scale fluid distribution on the physical properties of partially saturated tight sandstones. Journal of Applied Physics, 69, 1091-1098.

Gassmann F., 1951. Elastic waves through a pacing of spheres. Geophysics, 16, 4, 673- 685.

Jarzyna J., Bała M., Cichy A., Karczewski J., Marzencki K., Zorski T., Gądek W., Stadtmüller M., Twaróg W. \& Gąsior I., 2002. Przetwarzanie i interpretacja profilowań geofizyki wiertniczej - system GeoWin. Arbor, Kraków [with English abstract].

Karnkowski P., 1999. Oil and Gas Deposits in Poland. The Geosynoptics Society "Geos”, Cracow.

Knight R. \& Nolen-Hoeksema R., 1990. A laboratory study of the dependence of elastic wave velocities on pore scale fluid distribution. Geophysical Research Letters, 17, 10, 1529-1532.

Kuster G.T. \& Toksöz M.N., 1974. Velocity and attenuation of seismic waves in two-phase media. Part I: Theoretical formulations. Geophysics, 39, 5, 587-606.

Marzec P., Niepsuj M., Bała M. \& Pietsch K., 2014. The Application of Well Logging and Seismic Modeling to Assess the Degree of Gas Saturation in Miocene Strata (Carpathian Foredeep, Poland). Acta Geophysica, 62, 1, 83-115.

Mavko G., Chan C. \& Mukerji T., 1995. Fluid substitution: Estimating changes in $\mathrm{V}_{\mathrm{P}}$ without knowing $\mathrm{V}_{\mathrm{s}}$. Geophysics, 60, 1750-1755.

Myśliwiec M., 2004. Typy pułapek gazu ziemnego i strefowość występowania ich złóż w osadach miocenu wschodniej części zapadliska przedkarpackiego. Przegląd Geologicz$n y, 52,657-664$ [with English abstract].

Projekt prac geologicznych w rejonie Batycze, PGNiG, Jasło, 2006 [The geological project in the area of $\mathrm{B}, \mathrm{PGNiG}$, Jasło, 2006].

Toksöz M.N., Cheng C.H. \& Timur A., 1976. Velocities of seismic waves in porous rocks. Geophysics, 41, 621-645.

Oszczypko N., Ślączka A. \& Żytko K., 2008. Regionalizacja tektoniczna Polski - Karpaty zewnętrzne i zapadlisko przedkarpackie. Przegląd Geologiczny, 56, 10, 927-935 [with English abstract].

Zalewska J., 2009. Wyniki badań laboratoryjnych. [in:] Bała M., Cichy A., Jarzyna J., Mortimer Z., Pietsch K., Puskarczyk E., Marzec P., Witek K. \& Niepsuj M., 2009-2012, Modelowania teoretyczne i empiryczne wplywu zmiennego ciśnienia i nasycenia gazem na parametry sprężyste, gęstość $i$ oporność skat dla oceny przepuszczalności $z$ danych geofizyki otworowej, Projekt badawczy nr NN525 363537, Akademia Górniczo-Hutnicza im. St. Staszica w Krakowie, Kraków.

Wood A.W., 1955. A Textbook of Sound. MacMillan, New York. 